\title{
PENGARUH JENIS PUPUK ORGANIK DARI FESES TERNAK TERHADAP PERTUMBUHAN TANAMAN KELOR (Moringa oliefera L.)
}

\section{(THE INFLUENCE OF ORGANIC FERTILIZER TYPES FROM ANIMAL FESES ON THE GROWTH OF Moringa (Moringa oliefera) PLANTS)}

\author{
Viktor J. Dami ${ }^{1}$ \\ Arnold Ch. Hendrik ${ }^{1}$ \\ Hartini R.L Solle ${ }^{1}$ \\ 1'Program Studi Pendidikan Biologi, Fakultas Keguruan Dan Ilmu Pendidikan, \\ Universitas Kristen Artha Wacana, Kupang-NTT \\ Corresponding author : victordami2104@gmail.com
}

\begin{abstract}
ABSTRAK
Kelor merupakan tanaman yang bergizi dan memiliki berbagai manfaat potensial. Penelitian ini bertujuan untuk mengetahui pengaruh pupuk organik pada pertumbuhan tanaman kelor. Penelitian dilakukan menggunakan Rancangan Acak Lengkap (RAL) dengan 4 perlakuan dan 5 ulangan. Parameter yang diukur adalah tinggi tanaman, jumlah daun, dan diameter batang. Analisis data menggunakan analisis of varians (Anova) dan uji lanjutan Duncan Multiple Range Test (DMRT). Berdasarkan hasil uji anova pada taraf $5 \%$ pemberian pupuk organik pada kelor berpengaruh signifikan pada pertumbuhan tinggi tanaman ( $p$ $<0,05)$, diameter batang $(p<0,01)$ tetapi tidak berpengaruh signifikan pada jumlah daun pada $p>0,05$. Berdasarkan uji lanjut Duncan Multiple Range Test pada tinggi tanaman perlakuan A (Kontrol) memberikan pengaruh paling tinggi tetapi tidak berbeda secara signifikan dengan perlakuan $\mathrm{C}$ (pupuk kotoran kambing) sedangkan berbeda secara signifikan dengan perlakuan B (pupuk kotoran sapi) dan perlakuan D (pupuk kompos sufmuti). Pada diameter batang perlakuan $C$ (pupuk kotoran kambing) memberikan pengaruh paling tinggi tetapi tidak berbeda secara signifikan dengan perlakuan A (kontrol) dan perlakuan B (pupuk kotoran sapi) tetapi berbeda secara signifikan dengan perlakuan D (pupuk kompos sufmuti). Berdasarkan hasil penelitian dapat disimpulkan bahwa pemberian pupuk organik berpengaruh pada pertumbuhan tanaman kelor, terutama pada pertumbuhan tinggi dan diameter batang tanaman kelor dan pupuk kotoran kambing memberikan pengaruh terbaik pada tinggi tanaman, sementara pupuk kotoran sapi dan pupuk kotoran kambing memberikan pengaruh terbaik terhadap diameter batang tanaman kelor.
\end{abstract}

Kata kunci : Kelor, pupuk organik, tinggi tanaman, jumlah daun, dan diameter batang

\begin{abstract}
Moringa is a plant that nutritious and has all the benefit of potential. The purpose of this study is to determine the influence of organic fertilizer on the growth of moringa. The study was conducted in a completely randomized design (CDR) with four treatments and five replications. Parameters measured were plant heights, leaf number, and stem diameter. The data analyzed using the analysis of variance (ANOVA) then Duncan Multiple Range Test. The results showed that organic fertilizer significantly affect on the plant height and stem diameter at $p<0,05$ but not for the leaf number. Based on DMRT there is no significant difference on the height between treatment $A$ (control) and treatment $C$ (goat fertilizer) but significantly different from treatment $B$ (cow fertilizer) and treatment $D$ (sufmuti fertilizer). And then in diameter of stem treatment $C$ (goat fertilizer) has the highest influence but it is not significant different from treatment $A$ (control) and treatment $B$ (cow fertilizer) but significantly different from treatment $D$ (sufmuti fertilizer). The study concluded that the application of organic fertilizer has a positive influence on the growth of moringa, especially plant height and stem diameter, and the organic fertilizer that provided the best influence is goat fertilizer for plant height, then Both cow and goat fertilizers have the best influence on the stem diameter.
\end{abstract}

Keywords : Moringa, organic fertilizer, plant height, leaf number, stem diameter 


\section{PENDAHULUAN}

Tanaman kelor (Moringa oliefera L.) di Indonesia banyak ditemukan di Madura, Sulawesi, Nusa Tenggara Timur dan beberapa daerah lainnya. Kelor merupakan tanaman yang bernilai gizi tinggi dan memiliki berbagai manfaat potensial. Daun kelor mengandung bermacam-macam nutrisi seperti kalsium, zat besi, protein, dan berbagai macam vitamin. Daun kelor memiliki kandungan vitamin C sebanyak $220 \mathrm{mg} / 100 \mathrm{~g}$, zat besi sebanyak $0,7 \mathrm{mg} / 100 \mathrm{~g}$, dan protein sebanyak $6,7 \mathrm{mg} / 100 \mathrm{~g}$ (Krisnadi, 2015). Tanaman kelor memiliki banyak manfaat, sehingga tanaman ini perlu dikembangkan. Untuk mendapatkan hasil tanaman kelor yang berkualitas, penyediaan bibit yang berkualitas sangat diperlukan.

Menurut Sastro (2014) penambahan pupuk pada media tanam mampu meningkatkan kualitas bibit tanaman, khususnya pertumbuhan dan perkembangan akar, batang, dan daun yang lebih baik sehingga mampu meningkatkan penyerapan unsur hara. Unsur hara ini dapat diperoleh melalui pupuk anorganik dan pupuk organik. Pupuk organik adalah pupuk yang berasal dari materi makluk hidup seperti sisa-sisa tumbuhan, kotoran hewan, atau limbah organik yang sudah diuraikan oleh mikroba. Pupuk organik kaya akan kandungan unsur hara baik makro maupun mikro yang dibutuhkan oleh agar dapat tumbuh dengan subur. Pupuk organik terdiri dari beberapa jenis yaitu pupuk kandang, pupuk hijau, dan kompos (Winarni, 2013).

Pemberian pupuk organik dapat mencegah kerusakan lingkungan terutama degradasi lahan dan memperbaiki sifat fisik, kimia, dan biologi tanah, serta memperbaiki kesuburan tanah sehingga dapat menunjang pertumbuhan dan perkembangan tanaman (Haryadi, dkk. 2015). Selanjutnya dikemukakan oleh Mashud dkk (2013) kelebihan penggunaan pupuk organik adalah dapat memperbaiki keadaan tanah, meningkatkan daya simpan air pada tanah, meningkatkan kondisi kehidupan mikroorganisme, dan memberikan unsur hara yang lengkap bagi tanaman.

Bahan dasar untuk pembuatan pupuk organik dan proses pembuatannya menentukan kualitas pupuk yang dihasilkan. Keragaman kualitas pupuk organik akan memberikan pengaruh yang berbeda terhadap tanaman. Kajian tentang pengaruh pemberiaan pupuk organik yang berbeda terhadap tanaman kelor serta uji pupuk organik jenis apa yang dapat memberikan hasil optimal pada pertumbuhan tanaman kelor belum dilaporkan sampai saat ini.

Dalam penelitian ini tiga jenis pupuk organik yang diujikan, yaitu pupuk kandang kotoran sapi, pupuk kandang kotoran kambing, dan pupuk kompos tanaman sufmuti (Chormolaena odorata). Tanaman sufmuti (Chormolaena odorata) cukup potensial digunakan sebagai kompos karena kandungan unsur hara yang tinggi. Menurut Suntoro (2010), bahan organik sufmuti mengandung unsur $\mathrm{C}(50,4 \%)$, N (2,42\%), P (0,26\%), K (1,6\%), dan Mg (0,78\%).

Penelitian ini bertujuan untuk mengetahui pengaruh pemberian pupuk organik terhadap pertumbuhan bibit tanaman kelor dan untuk mengetahui jenis pupuk organik yang mampu memberikan pengaruh optimum pada pertumbuhan tanaman kelor.

\section{METODE PENELITIAN}

\section{Waktu dan Lokasi Penelitian}

Penelitian dilakukan di Kebun Pertanian Politeknik Pertanian Kupang yang bertempat di Desa Oesao, Kecamatan Kupang Timur, Kabupaten Kupang. Penelitian dilaksanakan pada bulan Maret hingga Mei 2019.

\section{Alat dan Bahan}

Alat yang digunakan adalah ember untuk mengambil tanah, cangkul, polybag, bak kecambah untuk perkecambahan, penggaris untuk mengukur tinggi tanaman kelor, jangka sorong untuk mengukur diameter batang tanaman, timbangan, kamera untuk dokumentasi,dan alat tulis untuk mencatat data penelitian. Bahan yang digunakan adalah biji kelor, tanah topsoil, air, kotoran sapi yang sudah matang sebagai bahan pembuatan pupuk kotoran sapi, kotoran kambing sudah matang sebagai bahan pembuatan pupuk kotoran kambing, tanaman sufmuti untuk pembuatan pupuk kompos sufmuti, jerami digunakan untuk campuran pupuk organik kotoran sapi, dan Effective Microorganisme (EM4) sebagai bioaktivator dalam pembuatan pupuk organik. 


\section{Prosedur Penelitian}

Prosedur penelitian dibagi menjadi dua tahapan yaitu pembuatan pupuk organik dan penanaman kelor.

Pembuatan Pupuk Organik

Pupuk kandang kotoran sapi

Kotoran sapi dicampur dengan sekam sebanyak $10 \%$ dari berat kotoran sapi, abu sekam sebanyak $10 \%$ dari berat kotoran sapi, dan dedak padi sebanyak $5 \%$ dari berat kotoran sapi diaduk merata lalu tuang larutan EM4. Larutan EM4 dibuat dengan cara mencampurkan $15 \mathrm{~mL}$ EM4 dengan $500 \mathrm{~mL}$ air bersih dan didiamkan selama 2 jam. Lalu pupuk ditutup dengan karung goni atau tikar. Lama fermentasi selama 15 hari. Proses fermentasi dapat dikatakan berhasil apabila sudah mengeluarkan bau khas fermentasi (Prihandini dan Purwanto, 2007).

\section{Pupuk kandang dari kotoran kambing}

Kotoran kambing yang digunakan adalah kotoran yang sudah matang secara alami. Sebelum difermentasikan, kotoran kambing terlebih dahulu dihancurkan. Kemudian kotoran kambing tersebut disiram dengan larutan EM4 secara merata. Larutan EM4 dibuat dengan cara mencampurkan $15 \mathrm{~mL}$ EM4 dengan $500 \mathrm{~mL}$ air bersih dan didiamkan selama 2 jam. Tutup tumpukan kotoran kambing menggunakan karung goni atau tikar. Kotoran kambing akan dibalik setiap 3 hari hingga selesai fermentasi. Proses fermentasi selama 15 hari. Apabila pupuk kompos sudah memiliki ciri-ciri berwarna cokelat kehitaman, memiliki tekstur yang gembur, dan tidak berbau busuk maka dapat dikatakan proses fermentasi berhasil (Trivana, 2017).

Pupuk kompos dari tanaman sufmuti

Pupuk kompos sufmuti dibuat dengan menggunakan $8 \mathrm{~kg}$ tanaman sufmuti, kotoran sapi yang kering sebanyak $1 \mathrm{~kg}$ dan sekam padi yang dibakar sebanyak $1 \mathrm{~kg}$. Tanaman sufmuti yang digunakan adalah tanaman yang sudah kering. Semua bahan dikumpulkan dalam suatu wadah lalu disiram dengan larutan EM4. Larutan EM4 dibuat dengan cara mencampurkan $15 \mathrm{~mL}$ EM4 dengan $500 \mathrm{~mL}$ air bersih dan didiamkan selama 2 jam. Kemudian bahan kompos ditutup dengan plastik. Pupuk difermentasi selama 15 hari. Setelah itu kompos siap digunakan.

\section{Penanaman dan Pemeliharaan}

Biji yang memiliki viabilitas tinggi disemai pada media yang terdiri atas campuran tanah, pasir,dan sekam padi dengan komposisi 3:1:1 (Krisnadi, 2015). Kecambah yang sudah bermur 5-12 hari sejak imbibisi dipindahkan ke media perlakuan di dalam polybag. Media perlakuan yang digunakan adalah kombinasi antara pupuk organik dan tanah dengan perbandingan sesuai perlakuan Penyiraman tanaman ddilakukan setiap 2-3 hari sekali tergantung pada kelembaban tanah, dengan volume air sebanyak 10-20 ml untuk tiap polybag.

\section{Penanaman dan Pemeliharaan}

Penelitian ini menggunakan Rancangan Acak Lengkap (RAL) dengan empat perlakuan dan lima kali ulangan, sehingga pada penelitian ini terdapat 20 unit percobaan. Setiap unit percobaan terdiri atas empat tanaman sehingga terdapat 80 tanaman kelor. Perlakuan pada penelitian ini adalah perbandingan kombinasi tanah dan pupuk organik seberat $2 \mathrm{~kg}$. Ke lima perlakuan berupa kombinasi tersebut meliputi

- Kombinasi antara $2 \mathrm{~kg}$ tanah dan $0 \mathrm{~kg}$ pupuk organik sebagai Perlakuan pertama (A)

- Kombinasi antara $1 \mathrm{~kg}$ tanah dan $1 \mathrm{~kg}$ pupuk kandang kotoran sapi sebagai Perlakuan kedua (B) 
- Kombinasi antara $1 \mathrm{~kg}$ tanah dan $1 \mathrm{~kg}$ pupuk kandang kotoran kambing sebagai Perlakuan ketiga (C)

- Kombinasi antara $1 \mathrm{~kg}$ tanah dan $1 \mathrm{~kg}$ pupuk kompos sufmuti sebagai Perlakuan keempat (D)

\section{Pengukuran Parameter}

Pengamatan dilakukan setiap 7 hari sekali dan dilakukan sebanyak 6 kali pengamatan. Parameter yang diukur adalah tinggi tanaman, jumlah daun, dan diameter batang. Pengukuran tinggi tanaman dilakukan dengan cara mengukur dari pangkal batang hingga ujung tunas tanaman menggunakan penggaris. Penghitungan daun dilakukan dengan cara menghitung setiap helai daun pada tanaman kelor. Pengukuran diameter batang menggunakan jangka sorong, letak jangka sorong dalam mengukur diameter batang adalah $1 \mathrm{~cm}$ di atas pangkal batang.

\section{Analisis Data}

Analisis data menggunakan Analisis of varians (Anova). Analisis lanjutan menggunakan Duncan Multiple Range Test (DMRT) dengan taraf 5\%.

\section{HASIL PENELITIAN}

\section{Tinggi Tanaman Kelor}

Jumlah rata-rata pertumbuhan tinggi tanaman kelor pada setiap perlakuan dapat dilihat pada Tabel 1. Berdasarkan analisis variansi (Anova) menunjukkan bahwa pemberian pupuk organik dengan jenis yang berbeda dapat memberikan pengaruh signifikan pada pertumbuhan tinggi tanaman pada nilai $p<0,05$. Pemberian pupuk organik secara signifikan menekan pertumbuhan tinggi tanaman kelor karena rata-rata tinggi tanaman pada perlakuan kontrol (tanpa pupuk organik) lebih tinggi dibanding dengan rata-rata tinggi tanaman pada setiap perlakuan yang menggunakan pupuk. Hasil uji Anova menunjukkan terdapat pengaruh sehingga dilakukan uji lanjutan menggunakan DMRT untuk melihat beda nyata setiap perlakuan. Uji lanjut DMRT menunjukan hasil antara perlakuan $A$ (kontrol) dan perlakuan $C$ (pupuk kotoran kambing) tidak berbeda secara signifikan sedangkan perlakuan A (kontrol) berbeda secara signifikan terhadap perlakuan B (pupuk kotoran sapi) dan perlakuan D (pupuk kompos sufmuti). Perlakuan C (pupuk kotoran kambing) tidak berbeda nyata dengan perlakuan B (pupuk kotoran sapi) dan perlakuan D (pupuk kompos sufmuti).

Tabel 1.Rata-rata pertumbuhan tinggi tanaman kelor setiap perlakuan

\begin{tabular}{ccccc}
\hline \multirow{2}{*}{ Ulangan } & \multicolumn{5}{c}{ Perlakuan } \\
\cline { 2 - 5 } & $\mathrm{A}$ & $\mathrm{B}$ & $\mathrm{C}$ & $\mathrm{D}$ \\
\hline 1 & 28,75 & 27,72 & 23,56 & 24,37 \\
\hline 2 & 33,12 & 21,75 & 24,51 & 24,89 \\
\hline 3 & 30,07 & 27,88 & 30,29 & 25,06 \\
\hline 4 & 31,56 & 23,65 & 26,97 & 27,08 \\
\hline 5 & 26,86 & 26,47 & 34,47 & 21,89 \\
\hline Jumlah & 150,36 & 127,47 & 139,80 & 123,29 \\
\hline Rata-rata & $\mathbf{3 0 , 0 7 ^ { \mathbf { A } }}$ & $\mathbf{2 5 , 4 9 ^ { \mathbf { B } }}$ & $\mathbf{2 7 , 9 6 ^ { \mathbf { A B } }}$ & $\mathbf{2 4 , 6 6 ^ { \mathbf { B } }}$ \\
\hline
\end{tabular}

Ket: Bilangan yang didampingi huruf yang sama menunjukkan tidak berbeda nyata berdasarkan uji DMRT 5\%.

\section{Jumlah Daun}

Jumlah rata-rata pertumbuhan daun tanaman kelor pada setiap perlakuan dapat dilihat pada Tabel 2. Berdasarkan analisis variansi (Anova) menunjukan bahwa pemberian jenis pupuk organik yang berbeda tidak mampu memberikan pengaruh pada pertumbuhan jumlah daun tanaman 
karena $p$ value $(\mathrm{sig})=0,276>0,05$, artinya perlakuan pupuk terhadap pertumbuhan daun tanaman kelor tidak memberikan pengaruh yang signifikan. Sehingga pada parameter ini tidak dilakukan pengujian lanjutan.

Tabel 2.Rata-rata pertumbuhan jumlah daun tanaman kelor setiap perlakuan Perlakuan

\begin{tabular}{ccccc} 
Ulangan & \multicolumn{1}{c}{} & B & C & D \\
\cline { 2 - 5 } & A & 83 & 77 & 82 \\
\hline 1 & 87 & 70 & 71 & 70 \\
\hline 2 & 81 & 74 & 90 & 69 \\
\hline 3 & 71 & 66 & 71 & 63 \\
\hline 4 & 84 & 71 & 86 & 73 \\
\hline 5 & 68 & 364 & 395 & 357 \\
\hline Jumlah & 391 & $\mathbf{7 3}$ & $\mathbf{7 9}$ & $\mathbf{7 1}$
\end{tabular}

\section{Diameter Batang}

Jumlah rata-rata pertumbuhan diameter batang pada setiap perlakuan dapat dilihat pada Tabel 3. Berdasarkan analisis variansi (Anova) menunjukan bahwa pemberian pupuk organik dengan jenis yang berbeda dapat memberikan pengaruh pada pertumbuhan diameter batang tanaman karena $p$ value(sig) $=0,005<0,05$. Sehingga untuk melihat beda nyata antar perlakuan maka dilanjutkan dengan pengujian menggunakan uji DMRT. Dari hasil uji lanjut DMRT menunjukan hasil antara perlakuan $C$ (pupuk kotoran kambing), perlakuan $A$ (Kontrol), dan perlakuan B (pupuk kotoran sapi) berbeda nyata dengan perlakuan D (pupuk kompos sufmuti).

Tabel 3.Rata-rata pertumbuhan diameter batang tanaman kelor setiap perlakuan

\begin{tabular}{ccccc}
\hline \multirow{2}{*}{ Ulangan } & \multicolumn{5}{c}{ Diameter Batang $(\mathrm{mm})$} \\
\cline { 2 - 5 } & $\mathrm{A}$ & $\mathrm{B}$ & $\mathrm{C}$ & $\mathrm{D}$ \\
\hline 1 & 35 & 34 & 35 & 34 \\
\hline 2 & 34 & 33 & 34 & 35 \\
\hline 3 & 34 & 34 & 39 & 30 \\
\hline 4 & 37 & 37 & 35 & 31 \\
\hline 5 & 34 & 35 & 39 & 31 \\
\hline Jumlah & 174 & 173 & 182 & 161 \\
\hline Rata-rata & $\mathbf{3 5}^{\mathbf{A}}$ & $\mathbf{3 5}^{\mathbf{A}}$ & $\mathbf{3 7}^{\mathbf{A}}$ & $\mathbf{3 2}^{\mathbf{B}}$
\end{tabular}

Ket:Bilangan yang didampingi huruf yang sama menunjukkan tidak berbeda nyata berdasarkan uji DMRT 5\%.

\section{PEMBAHASAN}

Pada parameter tinggi tanaman kelor, perlakuan $\mathrm{A}$ (Kontrol) memiliki nilai rata-rata tertinggi yaitu $30,07 \mathrm{~cm}$, diikuti perlakuan $\mathrm{C}$ (Pupuk kotoran kambing) dengan nilai rata-rata $27,96 \mathrm{~cm}$, lalu perlakuan B (pupuk kotoran sapi) dengan nilai rata-rata $25,49 \mathrm{~cm}$, dan yang terakhir adalah perlakuan $D$ (pupuk kompos sufmuti) dengan nilai rata-rata $24,66 \mathrm{~cm}$. Pertumbuhan tinggi pada tanaman kelor adalah pertumbuhan dasar yang terjadi karena adanya pembelahan sel-sel jaringan meristem primer yang terletak di ujung akar dan ujung batang tanaman. Proses ini merupakan sintesa protein yang diperoleh tanaman dari lingkungan seperti bahan organik dalam tanah. 
Pemberian bahan organik yang mengandung nitrogen dapat mempengaruhi kadar nitrogen total dalam tanah yang dapat berfungsi untuk mengaktifkan sel-sel tanaman dan mempertahankan jalannya proses fotosistesis yang ada (Rina, 2015).

Selanjutnya menurut Anggraeni (2018) unsur hara nitrogen berperan dalam merangsang pertumbuhan tanaman secara keseluruhan, untuk sintesis asam amino dan protein dalam tanaman, merangsang pertumbuhan vegetatif pada daun (warna, panjang, dan lebar) dan batang (tinggi dan ukuran diameter). Selain unsur hara nitrogen, tanaman membutuhkan unsur-unsur hara lainnya untuk menunjang pertumbuhan dan perkembangannya seperti kalium (K), fosfor (P), kalsium (Ca), magnesium (Mg), dan sulfur (S) (Ronabiha, 2007).

Dalam penelitian ini, Perlakuan A (kontrol) menunjukkan rata-rata tinggi tanaman kelor paling baik dengan rata-rata $30,07 \mathrm{~cm}$. Berdasarkan uji DMRT, perlakuan A (kontrol) tidak memiliki perbedaan signifikan dengan perlakuan $\mathrm{C}$ (pupuk kotoran kambing). Hal diduga karena tanah pada perlakuan kontrol dan pupuk kotoran kambing pada perlakuan $\mathrm{C}$ memiliki kandungan hara yang cukup untuk kebutuhan tanaman kelor baik itu secara makro maupun mikro. Saat unsur hara yang dibutuhkan tanaman telah tercukupi maka tanaman kelor akan mengalami pertumbuhan dengan maksimal. Hal ini sejalan dengan pendapat dari Bustami, dkk(2012) yang mengatakan bahwa apabila faktor-faktor pendukung pertumbuhan tanaman seperti unsur hara yang seimbang, dosis pupuk yang tepat, serta nutrisi yang dibutuhkan terpenuhi maka pertumbuhan tanaman akan menjadi optimal.

Untuk hasil pertumbuhan terendah dari penelitian ini yaitu perlakuan D (pupuk sufmuti). Namun berdasarkan uji lanjut DMRT, perlakuan D (pupuk sufmuti) dan perlakuan B (pupuk kotoran sapi) tidak memiliki perbedaan yang signifikan. Hal ini diduga karena kadar nitrogen pupuk sufmuti yang lebih tinggi $(2,42 \%)$ dan pupuk kotoran sapi yang lebih rendah $(0,40 \%)$ dari pupuk kotoran kambing dan tanah yang digunakan sebagai kontrol. Terhambatnya pertumbuhan tanaman kelor ini diduga akibat dari media tanam yang digunakan mengalami kelebihan dan kekurangan unsur hara. Menurut Nisa (2016) pemberian pupuk pada tanaman mesti sesuai dengan kebutuhan tanaman, karena kelebihan atau kekurangan unsur hara pada media tanam dapat mengakibatkan pertumbuhan tanaman menjadi tidak maksimal.

Menurut Parintak (2018) kelebihan unsur nitrogen dalam tanah akan menyebabkan pencemaran tanah dan akan terakumulasi. Selain itu pemberian pupuk yang mengandung nitrogen tinggi dapat menurunkan $\mathrm{pH}$ tanah. Penurunan $\mathrm{pH}$ tanah akan menyebabkan tanah menjadi asam dan dapat menghambat aktivitas mikroorganisme pengurai yang berperan dalam penguraian bahan organik serta penyediaan unsur hara makro terutama unsur hara nitrogen dan fosfat sehingga tanah menjadi miskin unsur hara dan akan terjadi kekurangan unsur hara pada tanaman. Selanjutnya dikemukakan oleh Parintak (2018) bahwa tingginya tingkat keasaman tanah mengakibatkan terjadinya ketidakseimbangan unsur hara dalam tanah. Unsur hara makro yang dibutuhkan dalam jumlah besar seperti $\mathrm{Ca}, \mathrm{N}, \mathrm{P}, \mathrm{K}$, dan $\mathrm{Mg}$ tidak tersedia dalam jumlah cukup dan unsur hara mikro seperti $\mathrm{Al}, \mathrm{Mn}$, dan $\mathrm{Fe}$ yang dibutuhkan tanaman dalam jumlah sedikit mengalami peningkatan. Ketidakseimbangan unsur hara ini mengakibatkan tanaman mengalami keracunan.

Kekurangan unsur juga dapat menganggu pertumbuhan tanaman.Pertumbuhan tanaman akan terjadi secara maksimal apabila unsur hara yang dibutuhkan tumbuhan tersedia cukup dalam tanah. Namun menurut Ronabiha (2007), tanaman yang mengalami kekurangan unsur hara akan mengalami pertumbuhan yang lambat, baik dalam proses pembentukan klorofil daun sebagai dapur produksi makanan, pertumbuhan akar, proses asimilasi, respirasi, proses pembentukan protein, lemak dan karbohidrat menjadi terhambat, serta jaringan tanaman tidak kokoh.

Pada parameter pertumbuhan daun tanaman kelor, perlakuan dengan nilai tertinggi terdapat pada perlakuan $\mathrm{C}$ (pupuk kotoran kambing) dengan nilai rata-rata 79 helai daun, diikuti perlakuan A (kontrol) dengan nilai rata-rata 78 helai daun, lalu perlakuan B (pupuk kotoran sapi) dengan nilai rata-rata 73 helai daun, dan yang terakhir adalah perlakuan $D$ (pupuk kompos sufmuti) dengan nilai rata-rata 71 helai daun. Berdasarkan analisis variansi (Anova) pada jumlah daun tanaman kelor menunjukan bahwa pemberian pupuk organik dengan jenis yang berbeda tidak memberikan pada pertumbuhan jumlah daun tanaman karena $p$ value $(\mathrm{sig})=0,276>0,05$, artinya perlakuan 
pupuk terhadap pertumbuhan daun tanaman kelor tidak memberikan pengaruh yang signifikan sehingga pada parameter ini, tidak perlu dilakukan uji lanjut. Karena tidak ada pengaruh maka dapat disimpulkan bahwa semua pupuk memberikan pengaruh yang sama atau seluruh unsur yang terkandung dalam pupuk sama dalam mempengaruhi jumlah daun.

Menurut Febriantami dan Nusyirwan (2017) dalam pertumbuhan dan perkembangan daun unsur hara nitrogen sangat dibutuhkan oleh tanaman. Nitrogen akan diserap oleh tanaman dalam bentuk ion $\mathrm{NH}_{4}{ }^{+}$dan $\mathrm{NO}_{3}{ }^{-}$.Nitrogen yang diserap oleh tanaman berperan dalam pembentukan daun, dimana nitrogen akan membantu proses pembelahan dan pembesaran sel sehingga daun muda lebih cepat mencapai bentuk yang sempurna. Selain itu, unsur $P$ juga berpengaruh dalam proses pembentukan daun. Unsur $P$ berperan penting dalam proses fotosintesis dimana unsur $P$ berperan sebagai pembentuk gula fosfat yang sangat dibutuhkan tanaman dalam proses fotosintesis. Proses fotosintesis yang baik akan menghasilkan fotosintat yang akan digunakan tanaman untuk pertumbuhan dan perkembangan tanaman (Haryadi dkk, 2015).

Ketika unsur nitrogen yang diberikan cukup maka daun tanaman akan tumbuh semakin banyak dan melebar sehingga menghasilkan daun dengan permukaan yang luas. Hal ini akan meningkatkan proses fotosintesis. Hal ini didukung pendapat dari Wijayanti, dkk (2013) yang mengatakan bahwa kandungan nitrogen dalam pupuk kandang berperan dalam pertumbuhan vegetatif tanaman terutama dalam peningkatan jumlah daun. Ukuran daun yang semakin luas akan meningkatkan hasil fotosintat. Fotosintat yang dihasilkan akan ditranslokasikan kesemua bagian tanaman untuk mendukung pertumbuhan dan perkembangan tanaman, seperti pertambahan ukuran panjang atau tinggi tanaman, pembentukan cabang dan daun baru.

Pada parameter diameter batang tanaman kelor, perlakuan $\mathrm{C}$ (pupuk kotoran kambing) memiliki nilai tertinggi dengan nilai rata-rata $37 \mathrm{~cm}$, diikuti perlakuan $A$ (kontrol) dan perlakuan $B$ (Pupuk kotoran sapi) dengan nilai rata-rata $35 \mathrm{~cm}$, dan yang terakhir adalah perlakuan D (pupuk kompos sufmuti) dengan nilai rata-rata $32 \mathrm{~cm}$. Berdasarkan analisis variansi (Anova) menunjukan bahwa pemberian pupuk organik dengan jenis yang berbeda dapat memberikan pengaruh pada pertumbuhan diameter batang tanaman karena $p$ value(sig) $=0,005<0,05$ sehingga dilakukan uji lanjut menggunakan uji DMRT. Dari hasil uji lanjut DMRT menunjukan hasil antara perlakuan C (pupuk kotoran kambing), perlakuan A (Kontrol) dan perlakuan B (pupuk kotoran sapi) berbeda nyata dengan perlakuan D (pupuk kompos sufmuti). Pada perlakuan $\mathrm{C}$ (kotoran kambing) rata-rata diameter batang paling tinggi. Namun berdasarkan uji lanjut DMRT, perlakuan C (kotoran kambing) tidak berbeda nyata dengan $A$ (kontrol) dan B (kotoran sapi) terhadap pertumbuhan diameter batang tanaman kelor. Hal ini menunjukan bahwa pertumbuhan jaringan tanaman kelor ketiga perlakuan itu normal. Dengan demikian tidak adanya penampungan cadangan makanan pada vakuola batang induk. Hal ini diduga karena adanya keseimbangan antara unsur-unsur hara yang terkandung dalam pupuk kotoran kambing, tanah, dan pupuk kotoran sapi seimbang untuk kebutuhan pertumbuhan diameter tanaman.

Nitrogen merupakan salah satu unsur hara yang paling banyak dibutuhkan tanaman. Nitrogen mempunyai peran yang penting pada pertumbuhan diameter batang tanaman. Nitrogen berperan untuk memacu pertumbuhan dan perkembangan tunas, daun, dan produksi buah. Nitrogen berperan sebagai komponen dasar pada proses sintesis protein, enzim, asam amino, asam nukleat, dan bagian integral dari klorofil yang juga berperan untuk mengontrol semua reaksi metabolisme dalam tanaman. Penambahan ukuran diameter batang dapat terjadi apabil terjadi peningkatan kadar nutrisi. Ini menunjukkan bahwa tumbuhan memanfaatkan hasil fotosintesis untuk pertumbuhan tajuk, batang hingga daun. Penambahan ukuran diameter batang tanaman dapat terjadi ketika hasil fotosintesis didistribusikan ke daerah tajuk (Sayekti, dkk. 2016).

Perlakuan D (pupuk kompos sufmuti) memiliki nilai rata-rata diameter batang tanaman kelor paling rendah. Berdasarkan uji lanjut DMRT, perlakuan D (pupuk sufmuti) berbeda secara signifikan dengan perlakuan $\mathrm{C}$ (kotoran kambing), perlakuan A (kontrol), dan perlakuan B (kotoran sapi). Hal ini diduga karena tingginya kandungan unsur hara nitrogen pada pupuk kompos sufmuti sehingga $\mathrm{pH}$ tanah menjadi turun dan tanah menjadi asam. Turunnya $\mathrm{pH}$ tanah ini mengakibatkan aktivitas mikroorganisme pengurai bahan organik terhambat sehingga unsur hara $\mathrm{N}$ dan $\mathrm{P}$ tidak 
Indigenous Biologi

Jurnal pendidikan dan Sains Biologi

2(3) 2019

tersedia cukup. Hal ini mengakibatkan tanaman mengalami kekurangan unsur hara. Keadaan tanah yang asam akan mengakibatkan ketidakseimbangan kandungan unsur hara pada tanah, unsur hara makro yang dibutuhkan tanaman dalam jumlah yang banyak tidak cukup tersedia dan unsur hara mikro yang dibutuhkan dalam jumlah kecil mengalami peningkatan sehingga tanaman mengalami keracunan (Parintak, 2018).

\section{KESIMPULAN}

Pemberian pupuk organik menghasilkan penurunan secara signifikan pertumbuhan tinggi tanaman kelor. Pada diameter batang, pupuk organik berpengaruh secara signifikan untuk meningkatkan ukuran diameter batang. Pada pertumbuhan daun, pemberian pupuk organik tidak berpengaruh secara signifikan untuk pertumbuhan daun tanaman. Jenis pupuk organik yang memberikan pengaruh terbaik yaitu pupuk kotoran kambing terhadap tinggi tanaman, pupuk kotoran sapi dan pupuk kotoran kambing memberikan pengaruh terbaik terhadap diameter batang tanaman, dan pemberian pupuk sufmuti memberikan hasil terendah pada setiap parameter pengukuran pupuk organik tidak berpengaruh signifikan untuk jumlah daun.

\section{SARAN}

Penelitian lanjutan yang dapat dilakukan adalah untuk menentukan rasio optimum antara tanah dan pupuk organik bagi pertumbuhan tanaman kelor.

\section{DAFTAR PUSTAKA}

Bustami. Sufardi. Bakhtiar. 2012. Serapan Hara Dan Efisiensi Pemupukan Phosfat Serta Pertumbuhan Padi Varietas Lokal. Jurnal Fakultas Pertanian, Universitas Jabal Gafur. Banda Aceh. p.159-170

Damanik, J. 2009. Pengaruh Pupuk Hijau Kirinyuh (Chormolaena odorata L.) Terhadap Pertumbuhan Dan Produksi Jagung (Zea mays L.). Skripsi. Fakultas pertanian. Universitas Sumatra Utara. Medan

Dapa, D. 2016. Pengaruh Pemberian Pupuk Urea, Biourine Dan Kombinasinya Terhadap Tingkat Produktifitas Rumput Gajah Kate (Pennisetum purpureum Cv. Mott) Pada Setiap Umur Pemotongan. Skripsi. Universitas Warmadewa: Denpasar

Febriantami, A. \& Nusyirwan. 2017. Pengaruh Pemberian Pupuk Organik Cair Dan Ekstrak Rebung Terhadap Pertumbuhan Dan Hasil Tanaman Kacang panjang (Vigna sinensis L.). Jurnal Biosains 3(2) : 96-102. DOI: https://doi.org/10.24114/jbio.v3i2.7581

Haryadi, D., Yetti, H., \& Yoseva, S. 2015. Pengaruh Pemberian Beberapa Jenis Pupuk Terhadap Pertumbuhan Dan Produksi Tanaman Kailan (Brassica alboglabraL.). Jom Faperta 2(2).

Hernita. 2012. Penentuan Unsur Hara Nitrogen Pada Bibit Duku. Jurnal Hort. 22(1). p.29-36

Hilal, S., Parwata, I.G.M.A., \& Santoso, B.B. 2018. Pertumbuhan Bibit Tanaman Kelor (Moringa oleifera Lam.) Asal Biji pada Berbagai Fase Pindah Tanam Semai. Jurnal sains teknologi dan lingkungan 3(2) : 54-63

Krisnadi, D. 2015. Kelor Super Nutrisi. E-Book Edisi Revisi.Pusat Informasi dan Pengembangan Tanaman Kelor Indonesia Lembaga Swadaya Masyarakat-Media Peduli Lingkungan : Blora

Lakitan, B. 1993. Dasar-dasar Fisiologi Tumbuhan. Raja Grafindo Persada. Jakarta 
Luruk, M. 2017. Pengaruh Penambahan Tepung Daun Kelor (Moringa Olifer) Terhadap Kadar Vitamin C Dan Kadar Protein Biskuit. Skripsi. FKIP Universitas Kristen Artha Wacana: Kupang.

Marsono \& Lingga, 2003. Petunjuk Penggunaan Pupuk. Penebar Swadaya: Yogyakarta.

Mashud, N., Maliangkay, R.B., \& Nur, M. 2013. Pengaruh Pemupukan Terhadap Pertumbuhan Vegetatif Tanaman Aren Belum Menghasilkan. Jurnal Palma. Balai Penelitian Tanaman Palma. Manado 14(1). p.13-19

Nisa, K. 2016. Memproduksi Kompos Dan Mikro Organisme Lokal (MOL). Bibit Publisher. Jakarta

Parintak, R. 2018. Pengaruh Pemberian Pupuk Organik Cair dari Limbah Buah Pepaya dan Kulit Nanas Terhadap Pertumbuhan Kangkung Darat (Ipomea reptans Poir). Skripsi. FKIP. Universitas Sanata Dharma. Yogyakarta

Prihandini, P., \& Purwanto, T. 2007. Petunjuk Teknis Pembuatan Kompos Berbahan Dasar Kotoran Sapi. Pusat Penelitian dan pengembangan peternakan, Departemen Pertanian: Bogor

Ronabiha, M. 2007. Pengaruh Jenis Pupuk Organik Terhadap Pertumbuhan Awal Vegetatif Cabe Rawit (Capcisum frutencens L). Skripsi. FKIP Universitas Kristen Artha Wacana: Kupang.

Sayekti, R. S., Prajitno, D., \& Indradewa, D. 2016. Pengaruh Pemanfaatan Pupuk Kandang Dan Kompos Terhadap Pertumbuhan Kangkung (Ipomea retans) Dan Lele Dumbo (Clarias gariepinus) Pada Sistem Akuaponik. Jurnal Teknologi Lingkungan. 17 (2). p.108-117

Trivana, L., Pradhana, A., \& Manambangtua, A. 2017. Optimalisasi Waktu Pengomposan Pupuk Kandang Dari Kotoran Kambing Dan Debu Sabut Kelapa Dengan Bioaktivator Em4. Jurnal Sains dan Teknologi Lingkungan, Balai Penelitian Tanaman Palma.9(1). p.16-24

Wijayanti, M., Syamsoel, M., \& Pramono, E. 2013. Pengaruh Pemberian Tiga Jenis Pupuk Kandang Dan Dosis Urea Pada Pertumbuhan Dan Hasil Tanaman Cabai (Capssicum annum L.). Jurnal Agrotek Tropika. 1(2). p.172-178 